\title{
Nakil Öncesi Yükssek Serum D-dimer Düzeyi Allojenik Hematopoietik Kök Hücre Nakli Yapılan Hastalarda Sağkalımı Belirlemede Prognostik Bir Belirteç Olabilir
}

\author{
Pretransplant Elevated Serum D-Dimer Level May \\ Be A Prognostic Marker For Survival in Patients \\ Who Underwent Allogeneic Hematopoietic Stem \\ Cell Transplantation
}

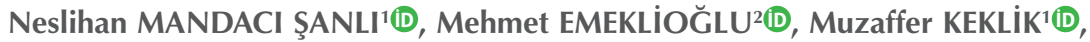 \\ Ali ÜNAL'D ${ }^{1}$ \\ ${ }^{1}$ Erciyes Üniversitesi Tıp Fakültesi, Hematoloji ve Kemik İliği Transplantasyonu Birimi, Kayseri, Türkiye \\ ${ }^{2}$ Erciyes Üniversitesi Tıp Fakültesi, Dahiliye Anabilim Dalı, Kayseri, Türkiye
}

öz

Amaç: Yüksek plazma D-dimer seviyeleri, hemostaz ve fibrinoliz aktivasyonunu gösterir ve bu aktivasyon, tümör anjiyogenezi, metastazı ve invazyonu ile sonuçlanabilmektedir. Ayrıca fibrin polimerinden üretilen D-dimer inflamasyon için bir belirteç olarak kullanılır. Yapılan çalışmalarda kronik inflamasyon ve kanser oluşumu arasında bir ilişki olduğu gösterilmiştir. Bu çalışmanın amacl, allojenik hematopoietik kök hücre nakli (allo-HKHN) yapılan hastalarda transplantasyon öncesi plazma D-dimer düzeyleri ile transplantasyon sonrası prognoz arasındaki ilişkiyi incelemektir.

Hastalar ve Yöntem: 2016-2019 yılları arasında allo-HKHN yapılan 98 hastanın verilerini geriye dönük olarak analiz ettik. Hastalar akut lösemi, lenfoma hastaları ve diğer hematolojik hastalık tanısına sahip hastalar olarak kategorize edildi. Sağkalımı tahmin etmek için D-dimer cut off değeri ROC (receiver operating curve) analizi ile $1630 \mathrm{mg} / \mathrm{dl}$ olarak belirlendi. Buna göre hastalar; transplantasyon öncesi D-dimer seviyeleri $<1630 \mathrm{mg} / \mathrm{dl}$ 'den düşük ve $\geq 1630 \mathrm{mg} / \mathrm{dl}$ ve $1630 \mathrm{mg}$ / dl'den yüksek olan hastalar olarak 2 gruba ayrıldı. İstatiksel değerlendirme için Kaplan-Meier survival analiz yöntemi ile tek ve çok değişkenli cox regresyon analizi kullanıldı.

Bulgular: Hastaların \%64.3'ü ( $n=63$ ) erkek, \%35.7'si ( $n=35$ ) kadındı. Genel sağkalım (GSK) bakımından serum $D$-dimer düzeyleri $<1630 \mathrm{mg} / \mathrm{dl}$ 'den düşük olan hastalar, serum D-dimer düzeyleri $\geq 1630 \mathrm{mg} / \mathrm{dl}$ 'den yüksek olan hastalar ile karşılaştırıldığında, D-dimer düzeyi $\geq 1630 \mathrm{mg} / \mathrm{dl}$ 'nin üzerinde olan olgularda sağkalım süresinin kısaldığı ve istatiksel olarak anlamlı olduğu tespit edilmiştir (tek değişkenli HO 3.942 [aralık 1.769-8.875] p= 0.001; çok değişkenli HO 3.727 [aralık 1.505-9.231] $\mathrm{p}=0.004$ ). Hastalıksız sağkalım (HSK) bakımından değerlendirildiğinde ise D-dimer değeri $\geq 1630 \mathrm{mg} / \mathrm{dl}$ 'den yüksek olgularda nükssüz sağkalım süresi istatistiksel olarak anlamlı derecede kısalmaktadır (tek değişkenli HO 2.707 [aralık 1.029-7.120] p= 0.044; çok değişkenli HO 4.214 [aralık 1.450-12.25] $\mathrm{p}=0.008$ ).

Sonuç: Allo-HKHN uygulanan hastalarda, nakil öncesi bakılan plazma D-dimer seviyesi, prognozun basit ama etkili bir öngörücüsü olarak hizmet edebilir.

Anahtar Kelimeler: D-dimer; Allojenik hematopoetik kök hücre nakli; Sağkalım; Prognoz

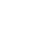




\section{ABSTRACT}

Objective: Elevated plasma D-dimer levels indicate activation of hemostasis and fibrinolysis, and this activation is required for tumor angiogenesis, metastasis, and invasion. İ addition D-dimer produced from fibrin polymer indicators for inflammation. The association between inflammation and cancer has been previously described. The aim of study is to examine the relationship between pretransplantation plasma D-dimer levels and prognosis among patients who underwent allogeneic hematopoietic stem cell transplantation (allo-HSCT).

Patients and Methods: We retrospectively analyzed the data of 98 patients who underwent alloHSCT from 2016 to 2019 . The patients were categorized as patients with acute leukemia, lymphoma patients, and other hematologic disease diagnoses. Pretransplant serum D-dimer levels were recorded. The cut-off value of D-dimer to predict survival was set as $1630 \mathrm{mg} / \mathrm{dl}$ based on the receiver operating curve analysis (ROC). Patients were divided into 2 groups; patients with pretransplant D- dimer levels lower than $<1630 \mathrm{mg} / \mathrm{dl}$ and higher than $\geq 1630 \mathrm{mg} / \mathrm{dl}$. Univariate, multivariate cox regression models and Kaplan-Meier curves were used for statistical analysis.

Results: The patients included 35 (35.7\%) female and 63 (64.3\%) male patients. Univariate and multivariate analysis showed that patients with serum D-dimer levels $\geq 1630 \mathrm{mg} / \mathrm{dl}$ experienced significantly lower overall survival (OS) compared with $<1630 \mathrm{mg} / \mathrm{dl}$ (HR 3.94 [range, 1.76-8.87] $p=0.001$ and HR 3.72 [range 1.50-9.23] $p=0.004$ ). For disease-free survival (DFS) evaluation, univariate and multivariate analysis showed that patients with serum D-dimer levels $\geq 1630 \mathrm{mg} / \mathrm{dl}$ had significantly lower disease-free survival compared with patients with serum D-dimer levels $<1630 \mathrm{mg} / \mathrm{dl}$ (HR 2.70 [range 1.02-7.12] $\mathrm{p}=0.044$ and HR 4.21 [range, 1.45-12.25] $\mathrm{p}=0.008$ ).

Conclusion: Pretransplant plasma D-dimer level may serve as a simple but effective predictor of prognosis in patients who underwent allo-HSCT.

Key Words: D-dimer; Allogeneic hematopoietic stem cell transplantation; Survival; Prognosis

\section{GíRiş}

Allojenik hematopoetik kök hücre nakli (allo-HKKN) doğumsal ve sonradan gelişen birçok kan hastalıklarında ve kanserlerinde kür sağlayabilen etkili bir tedavi yöntemidir $(1,2)$. Dünya genelinde kök hücre nakil sayısı her geçen yıl artmaya devam etmektedir. Kök hücre nakil başarısını başlıca nakil ilişkili mortalite, morbidite ve hastalık nüksü belirler (3). Bu nedenle yaşam ve mortaliteyi belirleyebilecek birtakım risk değerlendirmesinin yapılacağı moleküllerin belirlenmesi önemlidir. D-dimer bu anlamda kullanabileceğimiz bir belirteç olabilir.

Klinik ve deneysel çalışmalar kanser ve hemostaz arasındaki ilişkiyi ortaya koymasına rağmen kesin mekanizma tam olarak anlaşılamamıştır. Bu nedenle hemostaz ve koagülasyon sisteminin tromboz olmadan aktivasyonu üzerinde çalışmalar devam etmektedir (4-7).

D-dimer bir fibrin degradasyon ürünüdür ve aktive olmuş koagülasyon sisteminin ve fibrinolizisin sensitif bir göstergesi olarak kullanılmaktadır (8). Yüksek D-dimer seviyesine sahip kanser hastaları hatta sağlıklı kişilerde, normal popülasyona göre daha fazla artmış bir mortalite söz konusudur $(6,9)$. Tümör hücrelerinin kendisi veya inflamatuar sitokinler aracılığı ile koagülasyon kaskadının ve fibrinolizisin aktivasyonu, tömörün büyümesi, infiltrasyonu, metastazı, anjiogenezisinde önemli bir rol oynamaktadır $(10,11)$.

D-dimer inflamasyon için bir gösterge olarak kullanılmaktadır (12,13). Yapılan çalışmalarda kronik inflamasyon ve kanser oluşumu arasında bir ilişki olduğu gösterilmiştir (14).

Buradan yola çıkarak bu çalışmanın amacı nakil öncesi yüksek D-dimer seviyesi ile nakil sonrası hastaların prognozu arasındaki ilişkiyi araştırmaktır.

\section{HASTALAR ve YÖNTEM}

Çalışmaya retrospektif olarak 2016-2019 yılları arasında Erciyes Üniversitesi Tıp Fakültesi transplantasyon ünitesinde allo-HKHN yapılan 98 hasta alındı. Nakil öncesi serum D-dimer düzeyleri kayıt edildi. Sağkalımı tahmin etmek için D-dimer cut off değeri ROC (receiver operating curve) analizi ile 1630 mg/dl olarak belirlendi. Buna göre hastalar; transplantasyon öncesi serum D-dimer düzeyi <1630 mg/ dl'den düşük ve serum D-dimer düzeyi $\geq 1630 \mathrm{mg} / \mathrm{dl}$ ve üzerinde olan hastalar olarak 2 gruba ayrıldı. Çalışma için Erciyes Üniversitesi Etik Kurul Komitesinden onay alındı (Onay no: 2021/582).

\section{Transplantasyon Prosedürleri ve Profilaksi Stratejisi}

HKHN, standart transplantasyon prosedürlerine göre yapıldı. Miyeloablatif koşullandırma (MAC), siklofosfamid/ tüm vücut ışınlaması (TBI) veya siklofosfamid/busülfan'dan oluşuyordu. Miyeloablatif olmayan koşullandırma (NMA) esas olarak aplastik anemisi olan hastalara verildi. Aplastik anemili hastalarda koşulllandırma rejimi siklofosfamidden oluşmaktaydı. Azaltılmış yoğunluklu koşullandırma (RIC), fludarabin/busulfan, fludarabin/melphalan veya fludarabin/düşük doz TBI' dan oluşuyordu. Graft versus host hastalığı (GVHH) profilaksisi, metotreksat ve siklosporin A' dan oluşmaktaydı.

Nakil sonrası ilk 4 hafta antibakteriyel (moksifloksa$\sin 1$ x400 mg/gün) ve antiviral (valasiklovir 1x500 mg/ gün) profilaktik olarak uygulandı. Antifungal profilaksi için transplantasyon sonrası 75. güne kadar flukonazol 2×200 $\mathrm{mg} / \mathrm{gün}$ verildi. Pneumocystis jirovecii profilaksisi için engrafman sonrası 180. güne kadar trimetoprim $160 \mathrm{mg}$ ve sülfametoksazol 800 mg kombinasyonu günde 2 kez, haftada 2 gün olarak verildi. 


\section{Nakil İlişkili Değişkenlerin Tanımlanması ve İstatistik}

Transplant ilişkili risk sınıflanmasında 1. veya 2. komplet remisyonlu lösemi hastaları ve miyelodisplastik sendrom (MDS) hastaları standart riskli olarak değerlendirildi (15). Diğer tüm hastalar yüksek riskli olarak değerlendirildi. Birincil sonlanım genel sağkalım (GSK) ve hastalıksız sağkalım (HSK) idi. GSK, HKHN sonrası herhangibir nedenden ölüme kadar geçen süre olarak ölçüldü. HSK, HKHN tarihinden itibaren hastalığın nüksetmesinin radyolojik veya histolojik olarak doğrulanmasına kadar geçen süre (ay olarak) tanımlandı.

İstatistiksel analizde iki grup arasındaki sürekli değişkenler için Mann-Whitney U testi kullanıldı. Hayatta kalma ve ölüm olasılıkları Kaplan-Meier yöntemi kullanılarak tahmin edildi ve karşılaştırmalar log-rank testi kullanılarak yapıldı. Sağkalımı tahmin etmek için D-dimer düzeyi ROC analizi ile belirlendi. Ayrıca, hayatta kalma ve ölüm olasıIıkları üzerindeki en önemli risk faktörlerini belirlemek için tek değişkenli ve çok değişkenli cox regresyon analizleri uygulandı. Hazard oranları (HO) \%95 güven aralığı ile birlikte verildi. $\mathrm{P}<0.05$ istatistiksel olarak anlamlı kabul edildi.

\section{BULGULAR}

\section{Hasta Karakteristikleri}

Çalışmaya retrospektif olarak 98 hastanın verileri kayıt altına alındı. Hastaların \%64.3'ü ( $n=63)$ erkek, \%35.7'si ( $n=$ 35) kadın idi (Hastaların tanımlayıcı özellikleri Tablo 1'de gösterilmiştir). Ortanca yaş 42 (19-65) olmakla birlikte hastaların çoğunu akut lösemi hastaları oluşturmaktaydı [akut lösemi 67 (\%68.3) lenfoma hastaları 6 (\%6.1) ve diğer hematolojik hastalık tanısına sahip hastalar 25 (\%25.5) (MDS, aplastik anemi, miyelofibrozis...)] olarak kategorize edildi. 10/10 doku uyumlu verici sayısı $79(\% 80,6)$ iken, doku uyumsuz verici sayısı 16 (\%16.3) idi. 3 (\%3.1) hastanın ise doku uyumlarına dosyalarından ulaşılamadı. Hastaların 76'sında (\%77.6) MAC kullanımı ile nakil yapılırken, 16'sına (\%16.3) NMA ile ve 4'üne (\%4.2) RIC ile nakil yapıldı. Olguların 57' sine (\%58.2) teşhis sonrası ilk bir yıl içerisinde nakil yapılırken, 41'ine (\%41.8) teşhis sonrası bir yıldan sonraki bir zamanda nakil yapıldı.

Çalışmaya katılan olguların \%30.6'sında $(n=30)$ akut GVHH, \%21.4'ünde $(n=21)$ kronik GVHH olduğu gözlenmiştir. Olguların takip süreleri 3 ile 42 ay arasında değişmekte olup, ortanca takip süresi 18.5 aydı. Olguların \%24.5'inde ( $\mathrm{n}=24)$ mortalite gözlenmiştir. Çalışmaya katılan olguların HSK süreleri 3 ile 42 ay arasında değişmekte olup, ortanca HSK süresi 13 ay olarak saptanmıştır. Olguların \%17.3'ünde ( $n=17)$ nüks gözlenmiştir ve olguların pretransplant serum D-dimer düzeyleri, $130 \mathrm{mg} / \mathrm{dl}$ ile 6500 $\mathrm{mg} / \mathrm{dl}$ arasında değişmekte olup, ortanca serum D-dimer düzeyi 910 mg/dl'dir.
Tablo 1. Hastaların tanımlayıcı özellikleri

\begin{tabular}{|c|c|}
\hline Değişkenler & Sonuçlar N (\%) \\
\hline Yaş $(<40 / \geq 40)$ & $45(45.9) / 53(54.1)$ \\
\hline Cinsiyet (erkek/kadın) & $63(64.3) / 35(35.7)$ \\
\hline \multicolumn{2}{|l|}{ Teşhis } \\
\hline Akut lösemi & $67(68.3)$ \\
\hline Lenfoproliferatif hastalık & $6(6.1)$ \\
\hline Diğer hastalıklar & $25(25.5)$ \\
\hline Risk grup (standart risk/yüksek risk) & $75(76.5) / 23(23.5)$ \\
\hline $\begin{array}{l}\text { Transplantasyona kadar geçen süre } \\
(<12 \text { ay/ } \geq 12 \text { ay })\end{array}$ & $57(58.2) / 41(41.8)$ \\
\hline \multicolumn{2}{|l|}{ Koşullandırma rejimi } \\
\hline MAC & $76(77.6)$ \\
\hline NonMAC & $16(16.3)$ \\
\hline RIC & $4(4.2)$ \\
\hline \multicolumn{2}{|l|}{ Doku uyumu } \\
\hline Tam uyumlu & $79(80.6)$ \\
\hline Tam uyumsuz & $16(16.3)$ \\
\hline Doku uyumu kayıtlı olmayan hasta sayısı & $3(1.1)$ \\
\hline CD $34^{+}$sayısı, $10^{6} / \mathrm{kg}$, ortanca (aralık) & $7.01(2.7-19.2)$ \\
\hline D-dimer, mg/dl, ortanca (aralık) & $910(130-6500)$ \\
\hline Enfeksiyon (evet) & $77(78.6)$ \\
\hline Akut GVHH (evet) & $30(30.6)$ \\
\hline Kronik GVHH (evet) & $21(21.4)$ \\
\hline HSK, ay, ortanca (aralık) & $13(3-42)$ \\
\hline GSK, ay, ortanca (aralık) & $18.5(3-42)$ \\
\hline
\end{tabular}

HSK: Hastalıksız sağkalım, GVHH: Graft-versus-host hastalığı, GSK: Genel sağkalım, MAC: Myeloablatif koşullandırma rejimi, NonMAC: Nonmyeloablatif koşullandırma rejimi, RIC: Azaltılmış yoğunluklu rejim.

Serum D-dimer düzeyi 1630 mg/dl altında; 64 olgunun yaşadığı (\%84.2); 12 ölümün gözlendiği; serum D-dimer düzeyi 1630 mg/dl ve üzerinde 10 olgunun yaşadığı (\%45.5); 12 ölümün gözlendiği izlenmiştir. Serum D-dimer düzeyine göre sağkalım oranları log rank test ile değerlendirildiğinde, sağkalım oranları arasında istatistiksel olarak anlamlı farklılık bulunmaktadır $(p=0.001 ; p<0.01)$. Serum D-dimer düzeyi yüksek olgularda GSK süresi kısalmaktadır (Şekil 1).

Serum D-dimer düzeyi 1630 mg/dl'nin altında olan 76 olgudan; 66 olguda (\%86.8) nüks gözlenmediği; 10 olguda ise nüks gözlendiği; Serum D-dimer düzeyi 1630 mg/ dl ve üzerinde olan 22 olgudan; 15 olguda (\%68.2) nüks gözlenmediği; 7 olguda ise nüks gözlendiği izlenmiştir. Serum D-dimere göre HSK oranları log rank test ile değerlendirildiğinde sağkalım oranları arasında istatistiksel olarak anlamlı farklılık bulunmaktadır $(p=0.034 ; p<0.05)$. Serum D-dimer düzeyi yüksek olgularda HSK süresi kısalmaktadır (Şekil 2). 


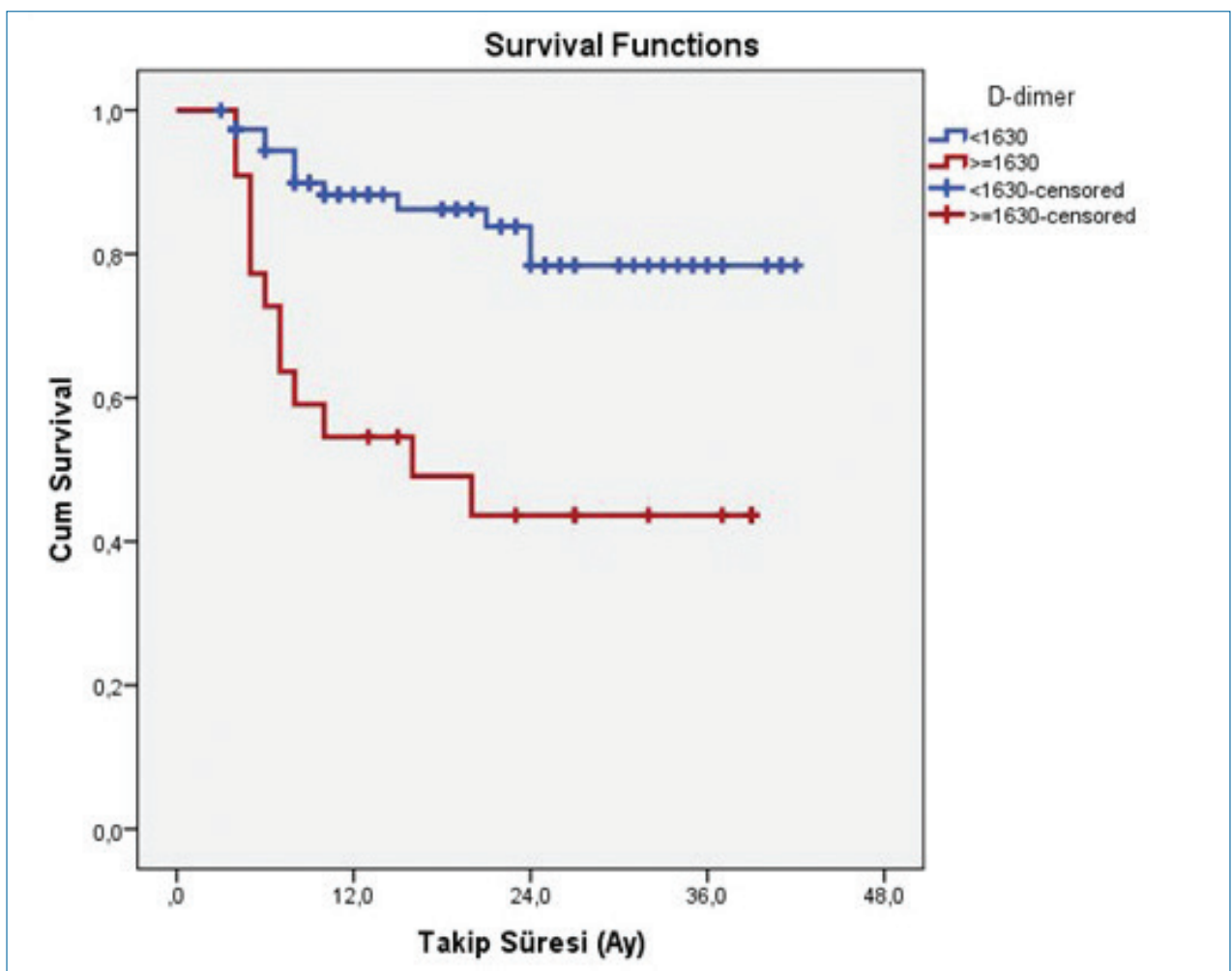

Şekil 1. Pretransplant serum D-dimer düzeyi $\geq 1630 \mathrm{mg} / \mathrm{dl}$ olan hastalarda genel sağkalım süresi istatistiksel olarak anlamlı bir şekilde kısalmaktadır $(p=0.001)$.

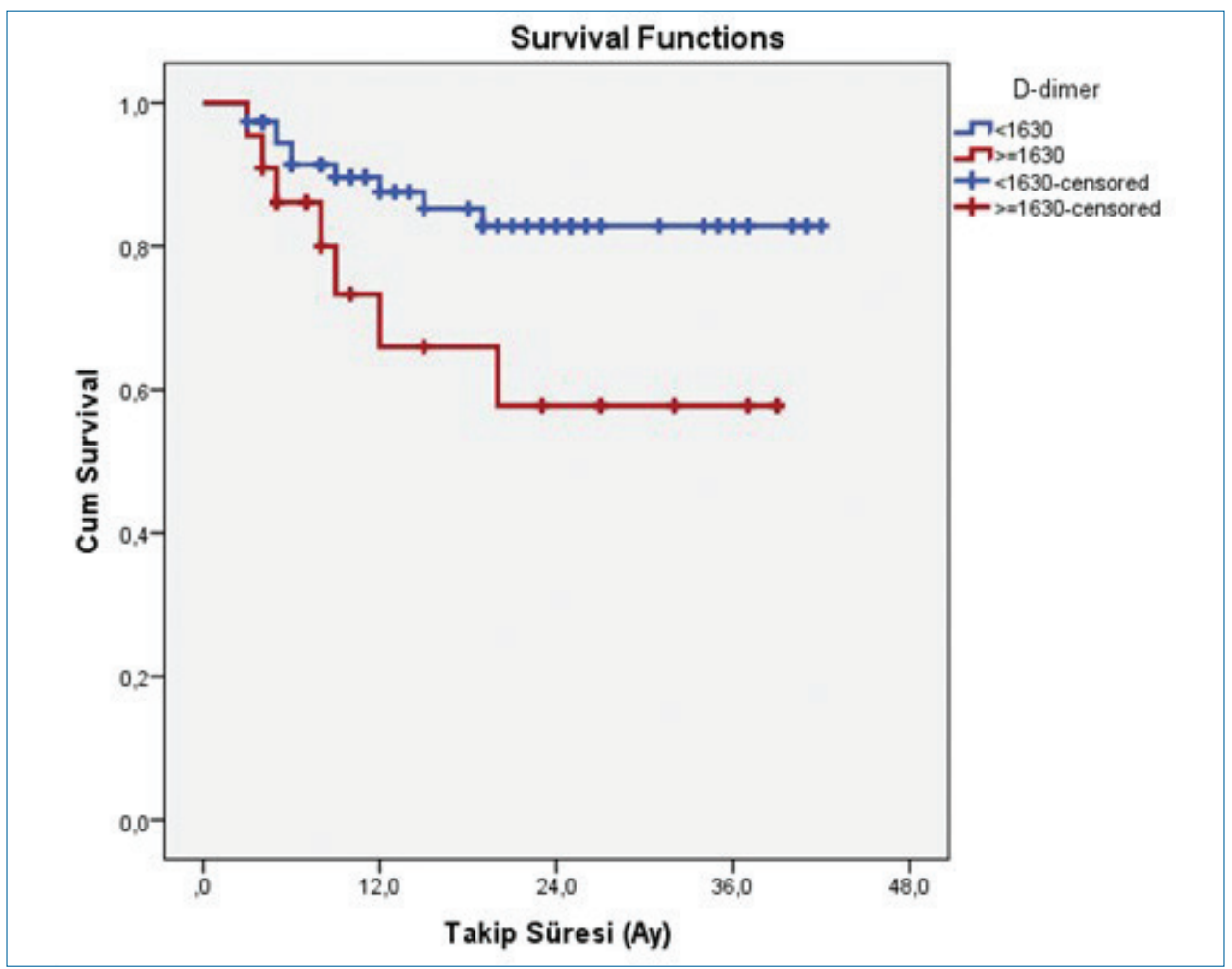

Şekil 2. Pretransplant serum D-dimer düzeyi $\geq 1630 \mathrm{mg} / \mathrm{dl}$ olan hastalarda hastalıksız sağkalım süresi istatistiksel olarak anlamlı bir şekilde kısalmaktadır $(p=0.034)$. 
GSK üzerine serum D-dimer düzeyinin etkisinin tek değişkenli cox regresyon analizi ile değerlendirildiğinde, istatiksel olarak anlamlı olduğu $(p<0.01)$ ve serum $D$-dimer düzeyi $\geq 1630 \mathrm{mg} / \mathrm{dl}$ üzerinde olan olgularda mortalite riskinin 3,942 (HO\%95:1.769-8.875) kat arttığı gözlenmiştir. Benzer şekilde hücre miktarı etkisinin tek değişkenli cox regresyon analizi ile değerlendirildiğinde istatistiksel olarak anlamlı olduğu $(p<0.05)$ gözlenmiştir. Fakat tek değişkenli olarak yaşın, cinsiyetin, enfeksiyonun, akut GVHH, kronik GVHH, risk durumu ve doku uyumu etkisinin istatistiksel olarak anlamlı olmadığı görülmektedir ( $p>0.05)$ (Tablo 2).

GSK üzerine etkili risk faktörlerinin çok değişkenli cox regresyon analizi ile değerlendirildiğinde serum D-dimer düzeyinin $\geq 1630 \mathrm{mg} / \mathrm{dl}$ olan olgularda mortalite riskinin
3,727 (HO\%95:1.011-1.076) kat arttığı ve istatistiksel olarak anlamlı olduğu tespit edilmiştir $(p<0.01)$. Benzer şekilde doku uyumu uyumsuz olguların mortalite riskini 2,766 (HO\%95:1,046-7,316) kat ve hücre miktarının mortalite riskini 1,043 (HO\%95:1,011-1,076) kat arttırdığı görülmekle birlikte istatistiksel olarak anlamlılık tespit edilmiştir $(p<$ 0.01) (Tablo 2).

HSK üzerine yaşın, cinsiyetin, akut GVHH, kronik GVHH, risk durumu ve hücre miktarının etkisinin tek değişkenli cox regresyon analizi ile değerlendirildiğinde istatistiksel olarak anlamlı olmadığı tespit edilmiştir ( $p>0.05)$.

HSK üzerine serum D-dimer düzeyinin etkisinin tek değişkenli cox regresyon analizi ile değerlendirildiğinde istatiksel olarak anlamlı olduğu $(p<0.05)$ ve serum $D$-dimer

Tablo 2. Genel sağkalım (GSK) için tekli ve çoklu cox regresyon analizi

\begin{tabular}{|c|c|c|c|c|}
\hline \multirow[b]{3}{*}{ Değişkenler } & \multicolumn{4}{|c|}{ GSK } \\
\hline & \multicolumn{2}{|c|}{ Tekli } & \multicolumn{2}{|c|}{ Çoklu } \\
\hline & HO (\%95 GA) & $\mathbf{p}$ & HO (\%95 GA) & $\mathbf{p}$ \\
\hline \multicolumn{5}{|l|}{ Yaş. yıl } \\
\hline$<40$ & 1.00 & & & \\
\hline$\geq 40$ & $1.187(0.531-2.653)$ & 0.676 & & \\
\hline \multicolumn{5}{|l|}{ Cinsiyet } \\
\hline Erkek & 1.00 & & & \\
\hline Kadın & $1.576(0.705-3.522)$ & 0.268 & & \\
\hline \multicolumn{5}{|l|}{ Enfeksiyon } \\
\hline Yok & 1.00 & & & \\
\hline Var & $2.539(0.596-10.819)$ & 0.208 & & \\
\hline \multicolumn{5}{|l|}{ Akut GVHH } \\
\hline Yok & 1.00 & & & \\
\hline Var & $0.867(0.359-2.091)$ & 0.750 & & \\
\hline \multicolumn{5}{|l|}{ Kronik GVHH } \\
\hline Yok & 1.00 & & & \\
\hline Var & $0.575(0.195-1.694)$ & 0.315 & & \\
\hline \multicolumn{5}{|l|}{ Risk durumu } \\
\hline Düşük risk & 1.00 & & & \\
\hline Yüksek risk & $1.394(0.578-3.363)$ & 0.460 & & \\
\hline \multicolumn{5}{|l|}{ Doku uyumu } \\
\hline Tam uyumlu & 1.00 & & 1.00 & \\
\hline Tam uyumsuz & $2.186(0.860-5.557)$ & 0.100 & $2.766(1.046-7.316)$ & $0.040^{*}$ \\
\hline \multicolumn{5}{|l|}{ D-dimer } \\
\hline$<1630$ & 1.00 & & & \\
\hline$\geq 1630$ & $3.942(1.769-8.875)$ & $0.001^{* *}$ & $3.727(1.505-9.231)$ & $0.004^{* *}$ \\
\hline CD34+ sayısı & $1.031(1.001-1.062)$ & $0.045^{*}$ & $1.043(1.011-1.076)$ & $0.009^{* *}$ \\
\hline
\end{tabular}


Tablo 3. Hastalıksız sağkalım (HSK) için tekli ve çoklu cox regresyon analizi

\begin{tabular}{|c|c|c|c|c|}
\hline \multirow[b]{3}{*}{ Değişkenler } & \multicolumn{4}{|c|}{ HSK } \\
\hline & \multicolumn{2}{|c|}{ Tekli } & \multicolumn{2}{|c|}{ Çoklu } \\
\hline & HO (\%95 GA) & $\mathbf{p}$ & HO (\%95 GA) & $\mathbf{p}$ \\
\hline \multicolumn{5}{|l|}{ Yaş-yıl } \\
\hline$<40$ & 1.00 & & 1.00 & \\
\hline$\geq 40$ & $1.947(0.718-5.279)$ & 0.190 & $3.307(1.043-10.49)$ & $0.043^{*}$ \\
\hline \multicolumn{5}{|l|}{ Cinsiyet } \\
\hline Erkek & 1.00 & & & \\
\hline Kadın & $1.236(0.470-3.252)$ & 0.668 & & \\
\hline \multicolumn{5}{|l|}{ Enfeksiyon } \\
\hline Yok & 1.00 & & 1.00 & \\
\hline Var & $0.239(0.092-0.621)$ & $0.003^{* *}$ & $0.127(0.044-0.372$ & $0.001^{* *}$ \\
\hline \multicolumn{5}{|l|}{ Akut GVHH } \\
\hline Yok & 1.00 & & & \\
\hline Var & $0.852(0.300-2.422)$ & 0.764 & & \\
\hline \multicolumn{5}{|l|}{ Kronik GVHH } \\
\hline Yok & 1.00 & & & \\
\hline Var & $0.382(0.087-1.679)$ & 0.203 & & \\
\hline \multicolumn{5}{|l|}{ Risk durumu } \\
\hline Düşük risk & 1.00 & & & \\
\hline Yüksek risk & $1.424(0.501-4.044)$ & 0.507 & & \\
\hline \multicolumn{5}{|l|}{ Doku uyumu } \\
\hline Tam uyumlu & 1.00 & & 1.00 & \\
\hline Tam uyumsuz & 3.755 (1.361-10.359) & $0.011^{*}$ & $6.285(2.100-18.81)$ & $0.001^{*}$ \\
\hline \multicolumn{5}{|l|}{ D-dimer } \\
\hline$<1630$ & 1.00 & & 1.00 & \\
\hline$\geq 1630$ & $2.707(1.029-7.120)$ & $0.044^{*}$ & $4.214(1.450-12.25)$ & $0.008^{* *}$ \\
\hline CD34+ sayısı & $0.997(0.912-1.090)$ & 0.951 & & \\
\hline
\end{tabular}

GVHH: Graft-Versus-Host hastalığı, HO: Hazard oranı, GA: Güven aralı̆ı.

${ }^{*} \mathrm{p}<0.05$.

${ }^{* *} \mathrm{p}<0.01$.

düzeyi $\geq 1630 \mathrm{mg} / \mathrm{dl}$ üzerinde olan olgularda nüks riskinin 2,707 (HO\%95:1,029-7,120) kat arttığı gözlenmiştir (tablo 3). Benzer şekilde doku uyumunun etkisinin tek değişkenli cox regresyon analizi ile değerlendirildiğinde doku uyumsuz olanların nüks riskini 3,755 (HO\%95:1,361-10,359) kat arttırdığı ve istatiksel olarak anlamlı olduğu gözlenmiştir $(p<0.05)$.

HSK üzerine etkili risk faktörleri çoklu cox regresyon analizi ile değerlendirildiğinde, serum D-dimer düzeyi $\geq 1630 \mathrm{mg} / \mathrm{dl}$ üzerinde olan olgularda nüks riskinin 4,214 (HO\%95:1,450-12,25) kat artmış olduğu gözlenmiş olup istatistiksel olarak önemli derecede anlamlılık tespit edilmiştir ( $p=0.008$ ). Benzer şekilde 40 yaş ve üzerinde olan olgularda nüks riskinin 3,30 (HO \%95:1,043-10,49) kat ve doku uyumsuz olgularda nüks riskinin istatistiksel olarak anlamlı derecede 6,285 (HO \%95:2,100-18,81) kat arttığı izlenmiştir $(p<0.01)$.

\section{TARTIŞMA ve SONUÇ}

Biz retrospektif olarak yaptığımız bu çalışmada, allo-HKHN öncesi yüksek serum D-dimer seviyesine sahip hastaların nakilden sonraki dönemde azalmış genel sağkalıma ve azalmış hastalıksız sağkalıma sahip olduklarını tespit ettik (Şekil $1 p=0.001$, Şekil $2 p=0.034$ ). Ayrıca tek değişkenli ve çok değişkenli cox regresyon analizlerde yüksek serum D-dimer düzeyinin olumsuz bir bağımsız prognostik faktör olduğunu gözledik (genel sağkalım için $p=$ 0.004 , hastalıksız sağkalım için $p=0.008$ ). 
D-dimer bir fibrin yıkım ürünüdür. Venöz tromboemboli, kardiyovasküler hastalık, yaygın damar içi pıhtılaşma gibi çeşitli hastalıklarda artabilir $(4,17)$. Ayrıca Di Castelnuovo ve arkadaşları (9), sağlıklı insan popülasyonu üzerinde yaptığı çalışmalarında artmış D-dimer düzeyinin herhangibir nedenden dolayı oluşan ölüm olayı için bağımsız bir risk faktörü olduğunu göstermiştir.

Son yıllarda artmış serum D-dimer düzeyi ve tümör oluşumu arasındaki ilişki dikkat çekmektedir (18). Artmış serum D-dimer düzeyi ile kötü prognozun gösterildiği meme kanseri $(4,19)$, kolorektal kanser $(20,21)$, akciğer kanseri (22), mide kanseri (23), diffüz büyük B hücreli lenfoma (24) ve NKT hücreli lenfoma (25) hastalarında yapılmış çalışmalar mevcuttur.

D-dimerin tümör oluşumu üzerine nasıl etki ettiği konusunda altta yatan mekanizmalar araştırılmakla birlikte, koagülasyon ve hemostazın sistemik aktivasyonunun anjiogeneziste, tümör invazyonunda, tümör büyümesinde ve metastatik yayılımında etkili olduğu düşünülmektedir. D-dimer hemostaz aktivasyonunun göstergesi için kullanılan bir biyomarkırdır $(10,11)$. Ayrıca D-dimer inflamasyon için bir gösterge olarak kullanılır $(12,13)$. Koagülasyon sisteminin bir parçası olan fibrin ve fibrin yıkım ürünü olan D-dimer, dolaşımda bulunan çeşitli bağışıklık sistemi hücreleri ile (monosit, makrofaj, lökosit) ligand-reseptör etkileşimi ile çeşitli sitokinlerin salınımına yol açarak inflamatuar bir sürecin gelişmesine sebep olur. IL-6 bu sitokinlerden başlıcasıdır $(13,26,27)$. IL-6 proinflamatuar bir sitokindir. Ve karaciğerden akut faz reaktanı olan fibrinojen salınımını arttırır. Fibrinojen hemostaz ve koagülasyon sisteminin temel elemanı olmakla birlikte (28) fibrinojen ve fibrin yıkım ürünleri sistemik inflamatuar sinyallerin oluşmasındaki mekanizmalarda görev almaktadır. Oluşan kronik inflamasyon ise tümörün gelişmesine yol açacak bir ortam oluşturmaktadır (14). Örneğin; hastalarda gelişen kronik kolit durumu kolon kanserinin gelişmesine yol açabilmektedir (29).

Liu ve arkadaşlarının (24) 254 yeni tanı diffüz büyük B hücreli lenfoma hastası üzerinde yaptığı bir çalışmada, tanı anında yüksek serum D-dimer seviyesine sahip hastalarda genel sağkalım bizim çalışmamıza benzer bir şekilde azalmıştır $(p<0.001)$.

Bi ve arkadaşlarının (25) 84 NKT hücreli lenfoma hastası üzerinde yaptığı başka bir çalışmada ise serum D-dimer seviyesi tanı anında yüksek seyreden hastalarda genel sağkaIım istatistiksel olarak önemli ölçüde düşük tespit edilmiştir $(p=0.003)$. Nagasawa ve arkadaşlarının (30) pediatrik allo-HKHN yapılan 60 hasta üzerinde nakil sonrası koagülasyon faktör bozukluklarını inceledikleri bir çalışmada, nakil sonrası dönemde serum D-dimer seviyesi yüksek seyreden 19 hastada, bir yıllık dönemde prognozun olumsuz yönde etkilendiği ve mortalitenin gözlendiği, geriye kalan ve serum D-dimer seviyeleri normal olan 41 hastada ise mortalitenin izlenmediği gözlenmiştir.

Çalışmamızın bazı kısıtlayıcı özellikleri bulunmaktadır. Birincisi çalışmamız retrospektif olarak yapılmıştır. İkincisi serum D-dimer düzeyinin sağkalıma etkisi için yapılan çalışmalarda, optimal cut-off değeri sabit bir değer olmamakla birlikte değişken değerler cut-off olarak belirlenmiştir. Ve sonuncu olarak nakil sonrası dönemde genel sağkalım ve hastalıksız sağkalım oranları düşük olan hastalarda, hastaların serum D-dimer seviyelerinin nasıl değişkenlik gösterdiğini kaydetmek bulgularımızı desteklemesi konusunda önemli bir kanıt olabilirdi. Fakat hastaların nakil sonrası takip dönemlerinde, D-dimer düzeyleri konusunda yeterli kayıtlı dosya verimiz olmadığı için nakil sonrası D-dimer düzeylerini takip altına alamadık.

Sonuç olarak biz mevcut çalışmamızda allo-HKHN uygulanan hastalarda, nakil öncesi artmış serum D-dimer seviyesinin, kötü prognozun tespit edilmesinde basit ama etkili bir öngörücü olarak hizmet edebileceğini gösterdik. Mevcut bulgularımız, D-dimerin allo-HKHN olan hastalarda prediktif veya prognostik bir belirteç olarak kullanımı ile ilgili ileri çalışmalar ile doğrulanabilir.

\section{ETIK KURUL ONAYI}

Çalışma için Erciyes Üniversitesi Etik Kurul Komitesinden onay alındı (Onay no: 2021/582).

\section{ÇIKAR ÇATIŞMASI}

Yazarların çıkar çatışması bulunmamaktadır.

\section{MALI AÇIKLAMA}

Çalışma için doğrudan veya dolaylı mali destek alınmadı. Çalışma ile ilgili herhangi bir firma veya kişi ile ilgili ticari bağlantı yoktur.

\section{YAZAR KATKISI}

Literatür taranması: NMŞ, MK, ME; Vakaların takip ve tedavi aşamaları: NMŞ, ME, MK; Verilerin toplanması: NMŞ, ME, EÜ; Makalenin yazımı: NMŞ, MK, AU; Onaylama: NMŞ.

\section{KAYNAKLAR}

1. İso A, Neri M, Maglietta F, La Russa R, Turillazzi E. Hematopoietic stem cell transplantation: a bioethical lens. Stem Cells Int 2017:111

2. Zhao L, Chen S, Yang P, Cao H, Li L. The role of mesenchymal stem cells in hematopoietic stem cell transplantation: prevention and treatment of graf-versushost disease. Stem Cell Res Ther 2019:182(10);1-13.

3. Amini M, Kazemnejad A, Rasekhi A, Zayeri F, Hajifathali A, Tavakoli F. Application of latent class analysis in diagnosis of graft-versus-host disease by serum markers after allogeneic haematopoietic stem cell transplantation. Sci Rep 2020;3633(10):1-11. 
4. Kacan T, Yucel B, Bahar S, Celasun G, Seker Mm, Babacan N, et al. The prognostic value of high pretreatment plasma d-dimer levels in non-metastatic breast cancer patients with absence of venous thromboembolism. International Journal of Hematology and Oncology 2016;26(3):136-144.

5. Blackwell K, Haroon Z, Broadwater G, Berry D, Harris L, Lglhart JD, et al. Plasma D-dimer levels in operable breast cancer patients correlate with clinical stage and axillary lymph node status. J Clin Oncol 2000;18(3):600-8.

6. Ay C, Dunkler D, Pirker R, Thaler J, Quehenberger P, Wagner $O$, et al. High D-dimer levels are associated with poor prognosis in cancer patients. Haematologica 2012;97(8):1158-64.

7. Knowlson L, Bacchu S, Paneesha S, McManus A, Randall K, Rose P. Elevated D-dimers are also a marker of underlying malignancy and increased mortality in the absence of venous thromboembolism. J Clin Pathol 2010;63(9):818-22.

8. De Buyzere M, Philippé J, Duprez D, Baele G, Clement DL. Coagulation system activation and increase of $D$-dimer levels in peripheral arterial occlusive disease. Am J Hematol 1993;43(2):91-94.

9. Di Castelnuovo A, de Curtis A, Costanzo S, Persichillo M, Olivieri $M$, Zito F, et al. Association of D-dimer levels with all-cause mortality in a healthy adult population: findings from the MOLI-SANI study. Haematologica 2013;98(9):1476-80.

10. Buller HR, van Doormaal FF, van Sluis GL, Kamphuisen PW. Cancer and thrombosis: from molecular mechanisms to clinical presentations. J Thromb Haemost 2007;5(suppl 1):246-54.

11. Ruf W, Yokota $\mathrm{N}, \mathrm{Schaffner} \mathrm{F}$. Tissue factor in cancer progression and angiogenesis. Thromb Res 2010;125(suppl 2):S36-S38.

12. Lowe GD. Circulating inflammatory markers and risks of cardiovascular and non-cardiovascular disease. J Thromb Haemost 2005;3(8):1618-27.

13. Davalos $D$, Akassoglou K. Fibrinogen as a key regulatuar of inflammation in disease. Semin Immunopathol 2012;34:43-62.

14. Mantovani A, Allevena P, Sica A, Balkwill F. Cancer-related inflammation. Nature 2008;454:436-44.

15. Armand $\mathrm{P}$, Gibson $\mathrm{CJ}$, Cutler $\mathrm{C}$ et al. A disease risk index for patients undergoing allogeneic stem cell transplantation. Blood 2012;120:905-13.

16. Nannya Y, Kataoka K, Hangaishi A, Imai Y, Takahashi T, Kurokawa $M$. The negative impact of female donor/male recipient combination in allogeneic hematopoietic stem cell transplantation depends on disease risk. Transpl Int 2011;24:469-76.

17. Lorenzet R, Donati MB. Blood clotting activation, angiogenesis and tumor metastasis: any role for TFPI? Thromb Haemost 2002;87:928-9.
18. Ashok V. D-dimer as an alarming biomarker in various cancers: $A$ review of literature. Glob Med Therap 2018;1(3):1-4.

19. Batschauer APB, Figueiredo CP, Bueno EC, Ribeiro MA, Dusse LMS, Fernandes AP, et al. D-dimer as a possible prognostic marker of operable hormone receptor-negative breast cancer. Ann Oncol 2010;21(6):1267-72.

20. Yamamoto M, Yoshinaga K, Matsuyama A, Iwasa T, Osoegawa A, Tsujita $\mathrm{E}$, et al. Plasma D-dimer level as a mortality predictor in patients with advanced or recurrent colorectal cancer. Oncology 2012;83(1):10-5.

21. Blackwell K, Hurwitz H, Liebérman G, Novotny W, Snyder S, Dewhirst $M$, et al. Circulating D-dimer levels are better predictors of overall survival and disease progression than carcinoembryonic antigen levels in patients with metastatic colorectal carcinoma. Cancer 2004;101(1):77-82.

22. Fan S, Zhao G, An G. High pretreatment plasma D-dimer levels are associated with shorter overall survival in patients with small cell lung cancer. J Int Med Res 2019;47(1):215-24.

23. Go SI, Lee MJ, Lee WS, Cohoi HJ, Lee US, Kim RB, et al. D-dimer can serve as a prognostic and predictive biomarker for metastatic gastric cancer treated by chemotherapy. Medicine (Baltimore) 2015;94(30):e951.

24. Liu B, Li B, Zhou P, Yue W, Wang T, Wanget J, et al. Prognostic value of pretreatment plasma $D$-dimer levels in patients with diffuse large B cell lymphoma (DLBCL). Clin Chim Acta 2018;482:191-8.

25. Xi-wen B, Liang W, Wen-wen Z, Sun P, Yan S, Liu P, et al. High Pretreatment D-Dimer Levels Correlate with Adverse Clinical Features and Predict Poor Survival in Patients with Natural Killer/ T-Cell Lymphoma. PLOS ONE 2016:1-12.

26. Adams RA, Passino M, Sachs BD, Nuriel T, Akassoglou K. Fibrin mechanisms and functions in nervous system pathology. Mol Interv 2004;4(3):163-76.

27. Solovjov DA, Pluskota E, Plow EF. Distinct roles for the alpha and beta subunits in the functions of integrin alphaMbeta2. J Biol Chem 2005;280(2):1336-45.

28. Mosesson MW. Fibrinogen and fibrin structure and functions. J Thromb Haemost 2005;3(8):1894-904.

29. Xie J, Itzkowitz SH. Cancer in inflammatory bowel disease. World J Gastroenterol 2008;14(3):378-89.

30. Nagasawa M, Ohkawa T, Endo A, Mitsuiki N, Ono T, Aoki Y. Early coagulation disorder after allogeneic stem cell transplantation is a strong prognostic factor for transplantation-related mortality, and intervention with recombinant human thrombomodulin improves the outcome: a single-center experience. Int J Hematol 2013;98:533-42. 